Original Article

\title{
Influence of incubation temperature and embryonic motility on the growth of members of Caiman yacare (Daudin, 1802)
}

\author{
Influência da temperatura de incubação e da motilidade embrionária sobre o \\ crescimento dos membros de Caiman yacare (Daudin, 1802)
}

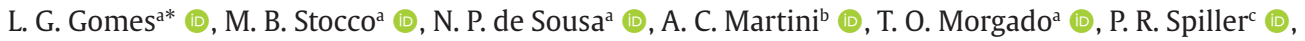 \\ L. F. B. Moreirad (i) and R. L. de Souza ${ }^{a}$ (D) \\ aUniversidade Federal de Mato Grosso - UFMT, Faculdade de Medicina Veterinária - FAVET, Cuiabá, MT, Brasil \\ bUniversidade de Mineiros - UNIFIMES, Departamento de Ciências Agrárias, Mineiros, GO, Brasil \\ ‘Universidade de Cuiabá - UNIC, Programa de Pós-Graduação em Biociência Animal, Cuiabá, MT, Brasil \\ dUniversidade Federal de Mato Grosso - UFMT, Instituto Nacional de Pesquisas do Pantanal - INPP, Museu Paraense Emílio Goeldi - MPEG, \\ Cuiabá, MT, Brasil
}

\begin{abstract}
This study aimed to evaluate whether skeletal development of the Pantanal Caiman (Caiman yacare) is similarly influenced by temperature variation and controlled increases in embryo motility. All eggs were incubated at $90 \%$ humidity and $29{ }^{\circ} \mathrm{C}$ for the first 45 days. Thereafter, the incubation temperature was either maintained at $29^{\circ} \mathrm{C}$ and embryos were treated with 4-aminopyridine (4-AP) on days 46, 47, 48, and 49 (Group I, $29{ }^{\circ} \mathrm{C} 4-\mathrm{AP}, \mathrm{n}=15$ ); maintained at $29^{\circ} \mathrm{C}\left(\mathrm{n}=14\right.$; Group II); or at $33^{\circ} \mathrm{C}(\mathrm{n}=14$, Group III). Embryonic movement was measured using an Egg Buddy ${ }^{\circledR}$ digital monitor on days $30,35,42,49,56$, and 60, at which point embryos were euthanized and samples were collected for analysis. No differences were observed between groups with varying incubation temperatures. In contrast, embryonic motility was greater in embryos treated with 4-AP $(\mathrm{P}<0.001)$ on day 49 , and this was associated with higher proportions of snout-vent and hand lengths. This study demonstrates for the first time that pharmacologically induced increases in embryo motility result in phenotypic changes to the proportion of elements during prenatal ontogeny, thereby effectively altering the adaptation of the species to specific environments.
\end{abstract}

Keywords: embryonic movement, temperature, Pantanal Caiman.

\begin{abstract}
Resumo
Este estudo objetivou avaliar os efeitos da temperatura e motilidade embrionária sobre o desenvolvimento esquelético de jacaré-do-pantanal (Caiman yacare). Os ovos foram incubados com $90 \%$ de umidade e empregouse a temperatura de $29^{\circ} \mathrm{C}$ por 45 dias. Após, para a incubação do Grupo I a temperatura continuou em $29^{\circ} \mathrm{C}$, mas associou-se à injeção de 4-aminopiridina $\left(29^{\circ} \mathrm{C}-4 \mathrm{AP}, \mathrm{n}=15\right)$ aplicada nos dias $46,47,48$ e 49 , do Grupo II permaneceu em $29^{\circ} \mathrm{C}(\mathrm{n}=14)$ e do Grupo III elevou-se para $33^{\circ} \mathrm{C}(\mathrm{n}=14)$. A movimentação foi mensurada através do monitor digital Egg Buddy ${ }^{\circledR}$ nos dias 30, 35, 42, 49, 56 e 60 dias. Aos 60 dias, os embriões foram eutanasiados e coletadas amostras embrionárias. Na análise estatística não foram observadas diferenças entre os grupos para o fator temperatura sobre a motilidade embrionária no desenvolvimento esquelético. Em contraste, a motilidade evidenciou diferença estatística no dia 49 para o Grupo I $(\mathrm{P}<0,001)$ e apresentou maiores proporções de nariz e mão. Esses dados demonstraram pela primeira vez que o aumento na motilidade, induzidos farmacologicamente resultam em divergências fenotípicas na proporção de segmentos anatômicos durante a ontogenia pré-natal, podendo alterar efetivamente a adaptação dos animais em ambientes específicos.
\end{abstract}

Palavras-chave: movimento embrionário, temperatura, jacaré-do-pantanal.

\section{Introduction}

The Pantanal Caiman belongs to the phylum Chordata, class Reptilia, subclass Archosauria, order Crocodylia, family Alligatoridae, genus Caiman, and species Caiman yacare (Azevedo, 2003; Marques, 2007; Lima et al., 2011a). They are generally distributed throughout Brazil, particularly in

hot climates, and as predators, they are important for the overall balance of their ecosystems (Naish, 2001). Six of the 25 species of alligators worldwide (Pincheira-Donoso et al., 2013) are found in Brazilian territory (Filogonio et al., 2010), and among these is the Pantanal Caiman. Several

*e-mail: liannaghisi@gmail.com

Received: June 1, 2021 - Accepted: October 20, 2021 
characteristic make the Pantanal Caiman an ideal choice of reptile for this study; first, it is categorized as Least Concern by the IUCN (Campos et al., 2020); there is a high abundance of the species at the study site; and finally, it has suitable biological characteristics as described by Pollard et al. (2017).

For this reptile class, nest temperature during the first 45-day period of incubation determines embryo sex. For the Pantanal Caiman, temperatures less than or greater than $30{ }^{\circ} \mathrm{C}$ result in females or males, respectively (Marques, 2007). Temperature also plays an important role in heart rate and embryonic movement of reptiles, this in turn, influences their metabolic rate, development (Du et al., 2009; Du et al., 2011), and ultimately, their behavioral patterns (Towers and Tickle, 2009).

Primary morphogenetic processes determine the pattern of skeletal growth in vertebrates and determine the emergence of mechanical or functional factors (Lima et al., 2011b; Pollard et al., 2014). As such, in addition to being necessary for normal skeletal development, embryonic movement also generates a mechanical load on the emerging skeletal structure; this mechanical load defines the proportion of limbs (Pollard et al., 2014), with new functionalities arising from subsequent changes to morphology (Lima et al., 2011b). In chickens, for example, increases in egg incubation temperature and inoculation with 4-aminopyridine (4-AP, which stimulates the release of acetylcholine, resulting in skeletal muscle hyperactivity), have been shown to increase embryo motility, consequently increasing limb length and modifying proportions of skeletal elements (Hammond et al., 2007; Pollard et al., 2014).

It is evident, therefore, that the embryonic behavior pattern of a given species is governed both by genetic factors and by non-genetic, environmental factors which together affect the reproductive and survival chances of the individual (Marques, 2007). Natural selection drives genetic change in species; however, environmental conditions determine behavioral patterns throughout the evolutionary process, and these patterns may perpetuate themselves to generate phenotypic variation during prenatal development (Pollard et al., 2017; Thampi et al., 2018).

Locomotor function and limb use in adults vary according to the length and proportions of its skeletal elements (Allen et al., 2014); thus, the influence of embryo motility on morphogenesis plays a critical role. Forces generated by cell movement during prenatal ontogeny regulate the condensation of cartilaginous elements in limb development, and growth, differentiation, death, and cellular directional motility are a result of forces exerted by the cytoskeleton (Pollard et al., 2014).

There is a plethora of experimental evidence detailing a direct relationship between embryonic motility and limb development, which is affected by incubation temperature (Pollard et al., 2014; Pollard et al., 2017). However, it remains unknown whether such phenomena occur in nature and whether these mechanobiological factors contribute to the emergence of phenotypic variation. Do such mechanical epigenetic influences play a fundamental role in the development of phenotypic characteristics? This question is perhaps best addressed in reptiles, which are excellent model organisms because they are ectothermic, oviparous, and their eggs are not incubated by the parents; this provides an opportunity to explore embryo motility and proportions of limbs at different temperatures that occur naturally in the reptile's nest (Pollard et al., 2017; Williamson et al., 2017).

Previous studies on the anatomy and development of Brazilian Caimans demonstrate phylogenetic lines with a dynamic sequence of evolutionary patterns, allowing each species to respond to particular habits; for example, skeletal plasticity (Lima et al., 2011b). The present study, therefore, analyzed information sources that could enrich the literature on the Pantanal Caiman. Inducing embryonic motility on morphogenesis via a mechanical stimulus causes mechanosensitive reactions, which in turn, stimulate the longitudinal growth of the limbs, alter the skeletal structure of individuals, and consequently, the proportion of limbs. The objective of this study was to assess the effects of temperature and embryonic motility as mechanical stimuli on the Pantanal Caiman during skeletal development.

\section{Materials and Methods}

The project was submitted to the Ethics Committee on Animal Use (CEUA) of the Federal University of Mato Grosso (UFMT) under protocol number 23108.321196/2017-53 and to the System of Authorization and Information on Biodiversity (SISBio) under protocol number 61288-2, for collections from the Zoological Park of UFMT.

The collection of the eggs followed the Ranching system, and egg identification, transportation, and incubation were undertaken with the required care for the Pantanal Caiman. The handling and transportation of eggs were carried out slowly and carefully. Nests were accessed through their upper portions, and layers were removed until the egg deposit chamber was reached. Each egg was marked (with an ' $X$ ') at the upper end to ensure its original orientation in the nest was maintained (Breyer, 1987).

The eggs were collected manually from the nest and placed side-by-side, $2-3 \mathrm{~cm}$ apart, inside plastic boxes containing a compact layer of $10-13 \mathrm{~cm}$ of organic material removed from the nest. A layer of nest material was then placed on the eggs and the boxes were closed and labeled according to the egg collection date and nest number. Finally, the eggs were transferred to appropriately labeled incubators, which had controlled temperature and humidity settings.

Throughout the incubation period, the humidity was maintained at $90 \%$. Given that sex determination of individuals is temperature dependent, and to avoid sexual dimorphism in growth rates, an incubation temperature of $29{ }^{\circ} \mathrm{C}$ was applied to all eggs for the first 45 days of incubation to ensure the development of female embryos. Thereafter, the temperature was either maintained at $29^{\circ} \mathrm{C}$ and hyperactivity was induced through the administration of $250 \mu \mathrm{L}$ injections of phosphate-buffered saline (PBS) containing $0.2 \mu \mathrm{g}$ of 4 -AP $\left(50 \mu \mathrm{g} / \mu \mathrm{L}\right.$, Sigma-Aldrich $\left.{ }^{\circledR}\right)$ onto the chorioallantois (Group I, $29^{\circ} \mathrm{C} 4-\mathrm{AP}, \mathrm{n}=15$ ) to stimulate the contraction of skeletal muscles; or the incubation temperature was maintained at $29{ }^{\circ} \mathrm{C}$ and PBS and 4-AP 
was not administered (Group II, $\mathrm{n}=14$ ), or the eggs were incubated at $33^{\circ} \mathrm{C}$ and PBS and 4-AP was not administered (Group III, $\mathrm{n}=14$ ).

In order to optimize the methods used for pharmacological stimulation of muscle contraction, a pilot study was first conducted in which several $250 \mu \mathrm{L}$ doses of $0.06 \mu \mathrm{g}$ of 4 -AP $(50 \mu \mathrm{g} / \mu \mathrm{L})$ were sequentially administered to eggs and embryo movement was monitored thereafter. Observations up to $1 \mathrm{~h}$ after the first administration of 4-AP showed no detectable change in embryo motility. After $1 \mathrm{~h}, 4 \mathrm{AP}$ was re-administered at the same dosage, and on this occasion, observations over the ensuing the $1 \mathrm{~h}$ period showed peaks of increased muscle contraction activity. Finally, a third $250 \mu \mathrm{L}$ dose of $0.06 \mu \mathrm{g}$ of 4 -AP was administered, and this resulted in increased levels of contractile activity of the skeletal muscles, which were maintained throughout the period of observation.

As described by Heywood et al. (2005), levels of hyperactivity were maintained in Group I $\left(29^{\circ} \mathrm{C} 4-\mathrm{AP}, \mathrm{n}=15\right)$ by administering $250 \mu \mathrm{L}$ injections of PBS containing $0.2 \mu \mathrm{g}$ of 4 -AP on days $46,47,48$, and 49 . To administer the injections, the eggs were opened and sealed with an adhesive to limit infection. Heartbeat and embryonic movements were measured using an Egg Buddy ${ }^{\circledR}$ egg digital monitor (Avian Biotech, Animal Genetics, England) on days $30,35,42,49,56$, and 60 ; on these days all of the eggs were briefly removed from the incubator and placed in the egg digital monitor for 2 min (Gomes et al., 2019).

The Pantanal Caiman was selected as the study species because it is widespread across South America; it can be found in the flooded regions of northeast and eastern Bolivia, the Brazilian Pantanal and tributaries of the Madeira River, in Paraguay, in northeastern Argentina and it has a population density of more than 100 individuals $/ \mathrm{km}^{2}$ throughout the flood plains of the Pantanal. In addition, from a conservation perspective, it is considered to be a species of lesser concern as it is not classified as an endangered species (Farias et al., 2013).

The embryos were euthanized in the final third of their development at 60 days of incubation, in strict accordance to the protocols defined in Federal Council of Veterinary Medicine (CFMV) Resolution $\mathrm{N}^{\circ} 1.000$, on March 11, 2012. Subsequently, the total length of each embryo, snout-vent, and limb was measured using a digital caliper, after which the limbs were removed and dissected. Finally, a portion of the collected samples, including the thoracic and pelvic limbs, were kept frozen at $-80{ }^{\circ} \mathrm{C}$, and the remaining portion was fixed in $10 \%$ formaldehyde for future analyses.

Statistical analyses were performed using $R \circledast$ (2013) software, version 3.2.0. Variance analysis (ANOVA) was performed using one factor (temperature) and repeated measurements (embryonic movement). For the proportion data, a logistic transformation was performed, followed by a t-test. Differences were considered significant at the 95\% confidence level (i.e., $\mathrm{P}<0.05$ ).

\section{Results}

We investigated whether incubation temperature changed the proportions of limbs and snout-vent lengths of Pantanal Caiman embryos. The incubation temperature was initiated at $29{ }^{\circ} \mathrm{C}$ for all eggs and maintained for 45 days, after which some of the eggs were incubated at $33^{\circ} \mathrm{C}$ and others at $29^{\circ} \mathrm{C}$. The length of the snout-vent, total limb length, and their elements were corrected for the size of the respective embryo at the time of euthanasia (60 days). Temperature variation did not cause changes to the uniform growth of the elements (Figures 1, 2, and 3), showing that temperature alone did not promote the growth of the snout-vent, limbs, and their elements.

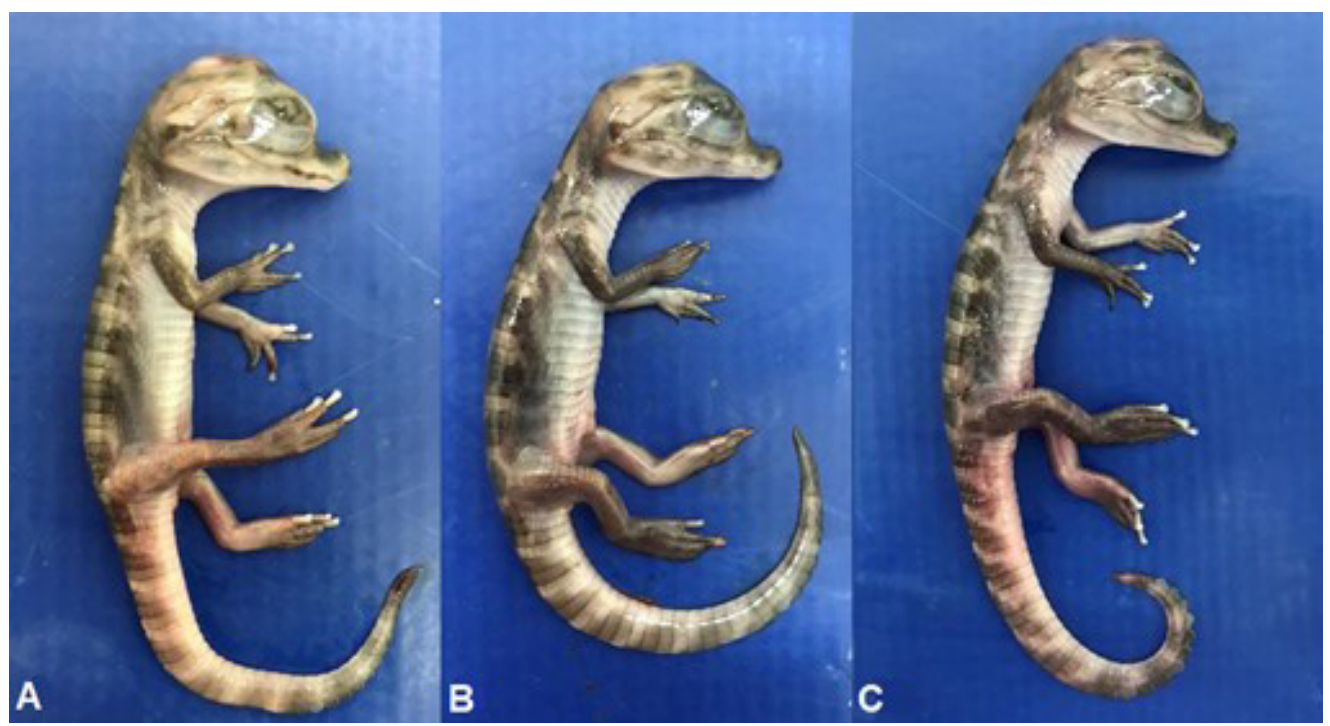

Figure 1. Pantanal Caiman (Caiman yacare) embryos incubated at different temperatures, (A) $29^{\circ} \mathrm{C}$ combined with the application of 4-aminopyridine (Sigma-Aldrich ${ }^{\oplus} 29^{\circ} \mathrm{C} 4$-AP), (B) $29^{\circ} \mathrm{C}$, and (C) $33^{\circ} \mathrm{C}$; euthanized at 60 days of incubation. 


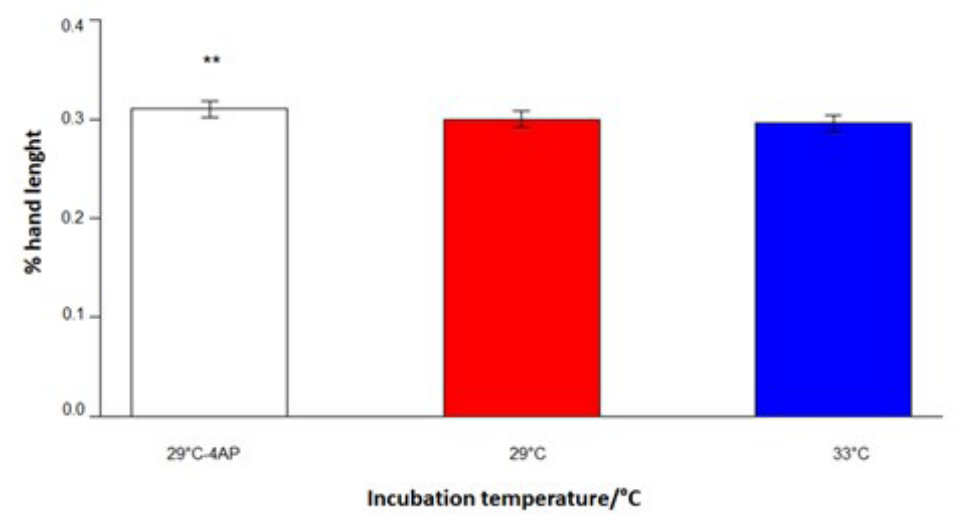

Figure 2. Proportion of hand length of Pantanal Caiman (Caiman yacare) embryos incubated at different temperatures, $29^{\circ} \mathrm{C}$ combined with the application of 4 -aminopyridine (Sigma-Aldrich $\left.{ }^{\oplus} ; 29^{\circ} \mathrm{C} 4-\mathrm{AP}\right), 29^{\circ} \mathrm{C}$, and $33^{\circ} \mathrm{C} 4-\mathrm{AP}\left({ }^{* *} \mathrm{P}<0.05\right)$.

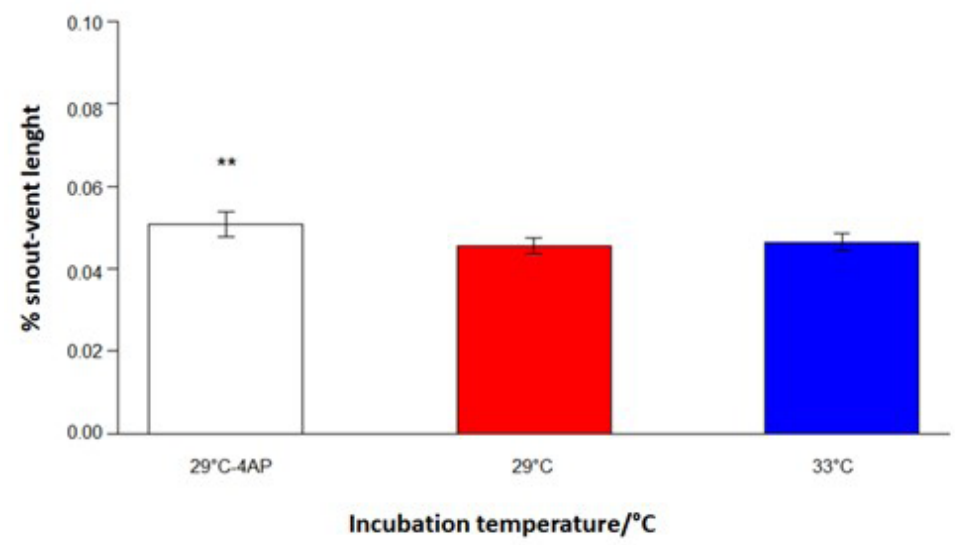

Figure 3. Proportion of the snout-vent length of Pantanal Caiman (Caiman yacare) embryos incubated at different temperatures, $29^{\circ} \mathrm{C}$ combined with the application of 4-aminopyridine (Sigma-Aldrich $\left.{ }^{\oplus} ; 29^{\circ} \mathrm{C} 4-\mathrm{AP}\right), 29^{\circ} \mathrm{C}$, and $33^{\circ} \mathrm{C}\left({ }^{* *} \mathrm{P}<0.05\right)$.

As expected, all embryos were found to be females, owing to the incubation of the eggs at the same temperature $\left(29^{\circ} \mathrm{C}\right)$ during the initial 45 days when sexual differentiation occurs in crocodiles (Azevedo, 2003).

Movement was evaluated on days 30, 35, 42, 45, 49, 56 , and 60 (Figure 4) during different stages of embryonic development. On day 30, the observed movement frequency means were lower than the other evaluated days, $24.57 \pm 41.06$, $22.78 \pm 46.13$, and $12.92 \pm 32.86$, for $33^{\circ} \mathrm{C}, 29^{\circ} \mathrm{C}$, and $29^{\circ}$ C 4-AP, respectively; this was because a portion of the eggs measured on day 30 did not present any movements. On day 49 , the observed movement frequency means were $101.92 \pm 5.62,119.92 \pm 6.98$, and $166.64 \pm 21.51$, for $29^{\circ} \mathrm{C}$, $33{ }^{\circ} \mathrm{C}, 29{ }^{\circ} \mathrm{C} 4-\mathrm{AP}$, respectively; demonstrating that 4-AP $\left(29^{\circ} \mathrm{C} 4-\mathrm{AP}\right)$ significantly $(\mathrm{P}<0.001)$ increased the frequency of embryonic movements. For days $35,42,45,56$, and 60 , embryonic movement remained stable between groups.

The proportions of both snout-vent length and limbs (hands) were significantly greater for embryos belonging to the $29{ }^{\circ} \mathrm{C}$ 4-AP group (Figures 2 and 3; P < 0.05). The embryos of the $33{ }^{\circ} \mathrm{C}$ and $29{ }^{\circ} \mathrm{C}$ groups showed no difference between the proportions of the snout-vent length, limbs, and their elements in relation to movement. These analyses provide insight into the growth alterations that occur due to increased embryonic motility through the application of 4-AP.

\section{Discussion}

The Pantanal Caiman was selected as the study species because Reptilia are excellent model organisms for this type of study; they are ectothermic, oviparous, and their eggs are not incubated directly by one of the parents (Pollard et al., 2017; Williamson et al., 2017). These characteristics provided an excellent opportunity to explore the impact of naturally occurring temperatures on the motility and proportions of limbs of Pantanal Caiman 


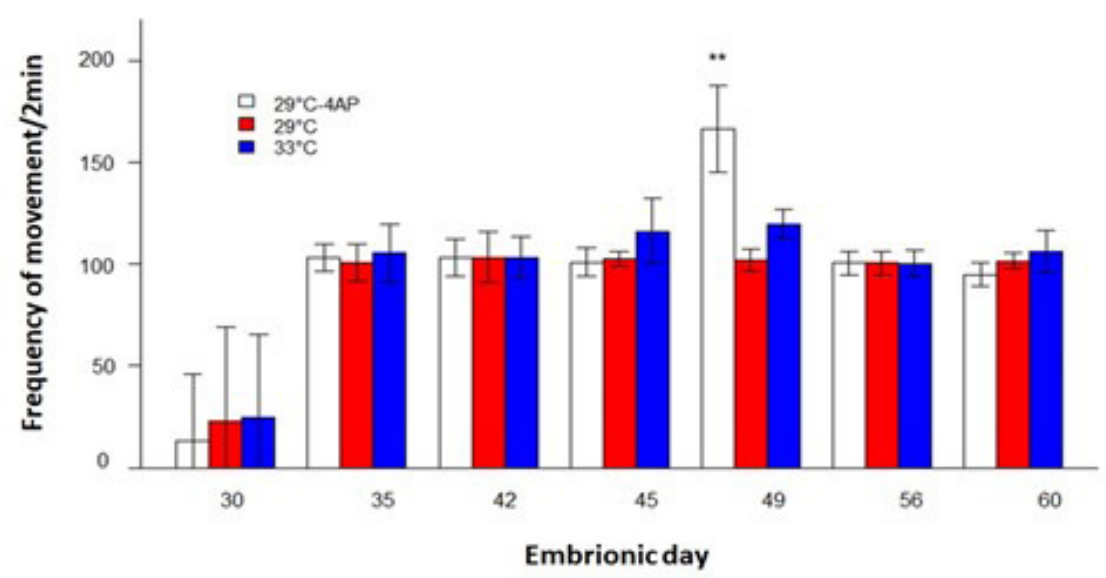

Figure 4. Frequency of embryonic movements evaluated with the aid of an Egg Buddy ${ }^{\circledR}$ digital monitor (Avian Biotech), for a period of two min/embryo, performed on days 30,35, 42, 45, 49, 56, and 60, to follow the medium and late incubation of the Pantanal Caiman (Caiman yacare; **P < 0.001). (Fonte: Gomes et al., 2019).

embryos; furthermore, this study facilitated the evaluation of egg incubation conditions that could be determined by the environment.

Prenatal ontogeny plays a role in characterizing a species, and species development may vary depending on environmental factors (Volynchik, 2014). However, the results for the present study showed that the temperatures used $\left(33^{\circ} \mathrm{C}\right.$ and $\left.29^{\circ} \mathrm{C}\right)$ for the Pantanal Caiman did not alter the proportions of the snout-vent, limbs, and their elements, as described by Miranda et al. (2002) and Marques (2007). Additionally, they also did not promote changes in the proportions of limbs and snout-vent, as described by Piña et al. (2007) in C. latirostris at the same temperatures. Finally, Pollard et al. (2017) reports that Osteolaemus tetraspis embryos incubated at different temperatures $\left(32{ }^{\circ} \mathrm{C}\right.$ and $28{ }^{\circ} \mathrm{C}$ ) show changes in the proportions of limbs in embryos.

The variation in Pantanal Caiman incubation temperature used in this study agrees with Miranda et al. (2002) and Marques (2007). However, it is possible that the discrepancies found in the existing literature are related to the species belonging to different families, i.e., Alligatoridae and Crocodylidae (Azevedo, 2003), explaining the differences found in the development of anatomical structures. In addition, the Pantanal Caiman and 0 . tetraspis are geographically distributed in regions with specific environmental features. As described by Calsbeek and Irschick (2007), this directly relates the habitat to the external morphology of these species, wherein environmental characteristics alter the proportions of limbs to improve the adaptation and performance of the locomotive system.

Although there are other methods for evaluating the detection of embryo egg movement, such as ovoscopes or "window" making, we used the Egg Buddy ${ }^{\circledR}$ digital monitor to detect blood pulse and embryonic movement.
This reliable method, as described by Pollard et al. (2016) and Gomes et al. (2019), is effective, as it does not require invasive techniques that could introduce the risk of infection. Furthermore, it has been safely used in studies on endangered species of birds and reptiles and it does not require euthanasia of embryos after the completion of the study. This method also limits external impacts, such as those caused by using an ovoscope. Finally, it is an easily transported system, which aids evaluation of the effect of physiological parameters on embryonic stimuli.

Embryonic motility was evaluated on days $30,35,42$, $45,49,56$, and 60 during the egg incubation of varying temperatures $\left(33^{\circ} \mathrm{C}\right.$ or $29^{\circ} \mathrm{C}$ ) and treatments (the application of 4-AP; $\left.29{ }^{\circ} \mathrm{C} 4-\mathrm{AP}\right)$. The lack of detectable movements in some embryos on day 30 is as a result of limitations of the equipment used in verifying movements in the initial phases of development (Pollard et al., 2016). However, despite the difficulty in obtaining motility data on this day, the effect of movement on the proportions of limbs and their elements was not affected; as described by Pitsillides (2006) and Nowlan et al. (2010), movement only influences the latter phases of development, with joint cavitation in limbs occurring in Pantanal Caiman only after 30 days of incubation (Lima et al., 2011b).

Movement on days 35, 42, 45, 56, and 60 was stable, and exhibited no statistical differences. From day 56 , there was a decline in movement compared to the previous evaluation at 49 days. This may have occurred because of embryo growth and the existence of a limiting physical egg space (Pollard et al., 2017) found during the start of the final incubation period.

The highest values of embryo movement for the eggs of the $29{ }^{\circ} \mathrm{C} 4$-AP group occurred on day 49 , differing significantly from that of the other groups; however, the embryos in the $33{ }^{\circ} \mathrm{C}$ group also showed relatively higher values of movement than those from the $29^{\circ} \mathrm{C}$ 
group. Motility was found to be a factor that promoted increased proportions of snout-vent and hands, and consequently, these findings are in agreement with those of Pitsillides (2006), and suggest that movement contributed to singular patterns of growth. Further support is provided by Pollard et al. (2017), who showed that the increased proportions of snout-vent lengths, limbs, and their elements in $\mathrm{O}$. tetraspis could be attributed to elevated movement during incubation at $32{ }^{\circ} \mathrm{C}$. Thus, the results of this study, combined with the existing literature confirm that movement is directly related to the growth of anatomical structures in reptiles.

The development of limb elements (stylopod, zeugopod, and autopod) determines the behavioral patterns of different species (Towers and Tickle, 2009), and according to Volynchik (2014) and Wilberg (2015), climatic variations are closely related to the movement and proportions of the limbs and their elements. Species with larger stylopods and zeugopods are better adapted to hot climates and are prone to terrestrialization, whereas species with smaller stylopods and zeugopods are better adapted to aquatic and colder habitats; the inverse of these characteristics holds true when considering autopod elements. Characteristics related to the structures of crocodilian skulls indicate that animals with narrow and long faces are better adapted to environments with greater water availability (Pereira and Malvasio, 2014).

We showed that the highest incubation temperature $\left(33^{\circ} \mathrm{C}\right)$ and addition of 4 -AP resulted in increased embryonic movement and increased proportions of the autopod elements and snout-vent length. This confirms that motility impacts the individual alteration of elements, as described by Pollard et al. (2014) and Pollard et al. (2017), and is a controlling factor in the behavioral characterization of a species.

Verdade (2001), Pereira and Malvasio (2014), Allen et al. (2014), and Böhmer et al. (2018) describe the existence of interspecific anatomical variation among crocodilians and their habitat requirements. Therefore, the increase in the proportion of hands and snout-vent lengths in Pantanal Caiman detected in this study could be attributed to morphological characteristics related to adapting to habitats with greater water availability.

Other discoveries prove that increases in the hand segment corresponds to individuals adapted to aquatic environments of extinct crocodilomorphs, talatosuquianos (Wilberg, 2015). This was previously described by Nevill et al. (2015), who found that an increase in the proportions of feet and hands represented optimal body proportions in human swimmers. Therefore, it has been suggested that an increase in the proportion of autopods could enhance the performance and adaptation of aquatic species.

In summary, temperature, and pharmacologically induced motility and mechanical load, cause changes in the external morphological proportions during prenatal ontogeny, which leads to species adaptation to specific environments. Additionally, we suggest that alterations in the epigenetic mechanisms of these animals can serve as indicators of the constantly increasing global temperature. Thus, these characteristics are related to phenotypic changes in Pantanal Caiman, based on temperature and motility, for better adaptation to the environment.

\section{References}

AZEVEDO, J.C.N., 2003. Crocodilianos: biologia, manejo e conservação. João Pessoa: ARPOADOR, 122 p.

BREYER, F.R.S., 1987. [viewed 1 June 2021]. Técnicas para a coleta, transporte e incubação artificial de ovos de Caiman crocodylus yacare (Daudin, 1802), (Crocodylia: alligatoridae). Corumba: EMBRAPA-CPAP, Comunicado Técnico EMBRAPA, vol. 8, pp. 1-8. Available from: https://www.embrapa.br/ busca-de-publicacoes/-/publicacao/787740/tecnicas-para-acoleta-transporte-e-incubacao-artificial-de-ovos-de-caimancrocodylus-yacare-daudin-1802-crocodylia-alligatoridae

ALLEN, V., MOLNAR, J., PARKER, W., POLLARD, A., NOLAN, G. and HUTCHINSON, J.R., 2014. Comparative architectural properties of limb muscles in Crocodylidae and Alligatoridae and their relevance to divergent use of asymmetrical gaits in extant Crocodylia. Journal of Anatomy, vol. 225, no. 6, pp. 569-582. http://dx.doi.org/10.1111/joa.12245. PMid:25418112.

BÖHMER, C., RAUHUT, O.W.M. and WÖRHEIDE, G., 2018. Correlation between Hox code and vertebral morphology in archosaurs. Proceedings of the Royal Society B. Biological Sciences. vol. 282, no. 1810, pp. 1-9. http://dx.doi.org/10.1098/rspb.2015.0077.

CALSBEEK, R. and IRSCHICK, D.J., 2007. The quick and the dead: correlational selection on morphology, performance, and habitat use in island lizards. Evolution; International Journal of Organic Evolution, vol. 61, no. 11, pp. 2493-2503. http:// dx.doi.org/10.1111/j.1558-5646.2007.00206.x. PMid:17725626.

CAMPOS, Z., LLOBET, A., MAGNUSSON, W.E. and PIÑA, C., 2020. Caiman yacare, Yacaré. The IUCN Red List of Threatened Species, vol. 2020, pp. e.T46586A3009881. https://dx.doi.org/10.2305/ IUCN.UK.2020-3.RLTS.T46586A3009881.en

DU, W.-G., RADDER, R.S., SUN, B. and SHINE, R., 2009. Determinants of incubation period: do reptilian embryos hatch after a fixed total number of heart beats? The Journal of Experimental Biology, vol. 212, no. Pt 9, pp. 1302-1306. http://dx.doi.org/10.1242/ jeb.027425. PMid:19376951.

DU, W.-G., YE, H., ZHAO, B., PIZZATTO, L., JI, X. and SHINE, R., 2011. Patterns of interspecific variation in the heart rates of embryonic reptiles. PLoS One, vol. 6, no. 12, pp. e29027. http:// dx.doi.org/10.1371/journal.pone.0029027. PMid:22174948.

FARIAS, I.P., MARIONI, B., VERDADE, L.M., BASSETTI, L., COUTINHO, M.E., MENDONÇA, S.H.S.T., VIEIRA, T.Q., MAGNUSSON, W.E. and CAMPOS, Z., 2013 [viewed 1 June 2021]. Avaliação do risco de extinção do Jacaré-do-Pantanal - Caiman yacare (Daudin, 1802) no Brasil. Biodiversidade Brasileira [online], vol. 3, no. 1, pp. 21-30. Available from: https://www.icmbio.gov.br/portal/ images/stories/biodiversidade/fauna-brasileira/avaliacao-dorisco/crocodilianos/Caiman_yacare.pdf

FILOGONIO, R., ASSIS, V.B., PASSOS, L.F. and COUTINHO, M.E., 2010. Distribution of populations of broad-snouted caiman (Caiman latirostris, Daudin 1802, Alligatoridae) in the São Francisco River basin, Brazil. Brazilian Journal of Biology = Revista Brasileira de Biologia, vol. 70, no. 4, pp. 961-968. http://dx.doi.org/10.1590/ S1519-69842010000500007. PMid:21180900.

GOMES, L.G., STOCCO, M.B., SOUSA, N.P., MARTINI, A.C., MORGADO, T.O., FLÔRES, F.N., MOREIRA, L.F.B., FERRAZ, R.H.S. and SOUZA, R.L., 2019. Método não invasivo para avaliação da movimentação embrionária de Caiman yacare (Daudin, 1802). Arquivo Brasileiro de Medicina Veterinária e Zootecnia, vol. 71, no. 6, pp. 2107-2110. http://dx.doi.org/10.1590/1678-4162-11260. 
HAMMOND, C.L., SIMBI, B.H. and STICKLAND, N.C., 2007. In ovo temperature manipulation influences embryonic motility and growth of limb tissues in the chick (Gallus gallus). The Journal of Experimental Biology, vol.210, no. Pt 15, pp. 2667-2675. http:// dx.doi.org/10.1242/jeb.005751. PMid:17644681.

HEYWOOD, J.L., MCENTEE, G.M. and STICKLAND, N.C., 2005. In ovo neuromuscular stimulation alters the skeletal muscle phenotype of the chick. Journal of Muscle Research and Cell Motility, vol. 26, no. 1, pp. 49-56. http://dx.doi.org/10.1007/ s10974-005-9007-8. PMid:16088375.

LIMA, F.C., SANTOS, A.L.Q., VIEIRA, L.G. and COUTINHO, M.E., 2011a. Sequência de ossificação do sincrânio e hioide em embriões de Caiman yacare (Crocodylia, Alligatoridae). Iheringia. Série Zoologia, vol. 101, no. 3, pp. 161-172. http://dx.doi.org/10.1590/ S0073-47212011000200003.

LIMA, F.C., VIEIRA, L.G., SANTOS, A.L.Q., PEREIRA, H.C., DE SIMONE, S.B.S., HIRANO, L.Q.L., ROMÃO, M.F., SILVA, J.M.M. and COUTINHO, M.E., 2011b [viewed 1 June 2021]. Skeletogenesis of the pectoral girdle and forelimbs in embryos of Caiman yacare (Daudin, 1802) (Crocodylia, Alligatoridae). Journal of Morphological Science Functional Anatomy and Cell Biology [online], vol. 28, no. 1, pp. 4-10. Available from: http://www.jms.periodikos. com.br/article/587cb4987f8c9d0d058b4777

MARQUES, M.S., 2007 [viewed 1 June 2021]. Estudo comportamental de Caiman yacare (Jacaré-do-Pantanal) in situ e ex situ. Revista Científica da Faminas [online], vol. 3, no. 3, pp. 1120. Available from: https://www.faminasbh.edu.br/upload/ downloads/200910151808079090.pdf

MIRANDA, M.P., MORAES, G.V., MARTINS, E.N., MAIA, L.C.P. and BARBOSA, O.R., 2002. Thermic variation in incubation and development of Pantanal Caiman (Caiman crocodilus yacare) (Daudin, 1802) kept in metabolic box. Brazilian Archives of Biology and Technology, vol. 45, no. 3, pp. 333-342. http:// dx.doi.org/10.1590/S1516-89132002000300012.

NAISH, D., 2001. Fossils explained: crocodilians. Geology Today, vol. 17, no. 2, pp. 71-77. http://dx.doi.org/10.1046/j.13652451.2001.00006.x.

NEVILL, A.M., OXFORD, S.W. and DUNCAN, M.J., 2015. Optimal body size and limb length ratios associated with $100-\mathrm{m}$ personal-best swim speeds. Medicine and Science in Sports and Exercise, vol. 47, no. 8, pp. 1714-1718. http://dx.doi.org/10.1249/ MSS.0000000000000586. PMid:25412299.

NOWLAN, N.C., SHARPE, J., RODDY, K.A., PRENDERGAST, P.J. and MURPHY, P., 2010. Mechanobiology of embryonic skeletal development: insights from animal models. Birth Defects Research. Part C, Embryo Today: Reviews, vol. 90, no. 3, pp. 203-213. https://doi.org/10.1002/bdrc.20184.

PEREIRA, A.C. and MALVASIO, A., 2014. Síntese das características da ordem Crocodylia, fatores de influência em estudos populacionais e aspectos de seleção e uso de habitat para Caiman crocodilus e Melanosuchus niger no Estado do Tocantins, Brasil. Biota Amazônia, vol. 4, no. 1, pp. 111-118. http://dx.doi.org/10.18561/2179-5746/biotaamazonia. v4n1p111-118.
PIÑA, C.I., LARRIERA, A., MEDINA, M. and WEBB, G.J.W., 2007. Effects of incubation temperature on the size of Caiman latirostris (Crocodylia: Alligatoridae) at hatching and after one year. Journal of Herpetology, vol. 41, no. 2, pp. 205-210. http:// dx.doi.org/10.1670/0022-1511(2007)41[205:EOITOT]2.0.CO;2.

PINCHEIRA-DONOSO, D., BAUER, A.M., MEIRI, S. and UETZ, P., 2013. Global taxonomic diversity of living reptiles. PLoS One, vol. 8, no. 3, pp. e59741. http://dx.doi.org/10.1371/journal. pone.0059741. PMid:23544091.

PITSILLIDES, A.A., 2006. Early effects of embryonic movement: 'a shot out of the dark'. Journal of Anatomy, vol. 208, no. 4, pp. 417-431. http://dx.doi.org/10.1111/j.1469-7580.2006.00556.x. PMid:16637868.

POLLARD, A.S., CHARLTON, B.G., HUTCHINSON, J.R., GUSTAFSSON, T., MCGONNELL, I.M., TIMMONS, J.A. and PITSILLIDES, A.A., 2017. Limb proportions show developmental plasticity in response to embryo movement. Scientific Reports, vol. 7, pp. 41926. http:// dx.doi.org/10.1038/srep41926. PMid:28165010.

POLLARD, A.S., MCGONNELL, I.M. and PITSILLIDES, A.A., 2014. Mechanoadaptation of developing limbs: shaking a leg.Journal of Anatomy, vol. 224, no. 6, pp. 615-623. http://dx.doi.org/10.1111/ joa.12171. PMid:24635640.

POLLARD, A.S., PITSILLIDES, A.A. and PORTUGAL, S.J., 2016. Validating a noninvasive technique for monitoring embryo movement $I n$ Ovo. Physiological and Biochemical Zoology, vol. 89, no. 4, pp. 331-339. https://doi.org/10.1086/687228.

THAMPI, P., LIU, J., ZENG, Z. and MACLEOD, J.N., 2018. Changes in the appendicular skeleton during metamorphosis in the axolotl salamander (Ambystoma mexicanum). Journal of Anatomy, vol. 233, no. 4, pp. 468-477. http://dx.doi.org/10.1111/joa.12846. PMid:29992565.

TOWERS, M. and TICKLE, C., 2009. Generation of pattern and form in the developing limb. The International Journal of Developmental Biology, vol. 53, no. 5-6, pp. 805-812. http://dx.doi.org/10.1387/ ijdb.072499mt. PMid:19557686.

VERDADE, L.M., 2001. Allometry of reproduction in broad-snouted caiman (Caiman latirostris). Brazilian Journal of Biology $=$ Revista Brasileira de Biologia, vol. 61, no. 3, pp. 431-435. http://dx.doi. org/10.1590/S1519-69842001000300012. PMid:11706570.

VOLYNCHIK, S., 2014. Climate-related variation in body dimensions within four lacertid species. International Journal of Zoology, vol. 2014, no. 795387, pp. 1-14. http://dx.doi. org/10.1155/2014/795387.

WILBERG, E.W., 2015. A new metriorhynchoid (Crocodylomorpha, Thalattosuchia) from the Middle Jurassic of Oregon and the evolutionary timing of marine adaptations in thalattosuchian crocodylomorphs. Journal of Vertebrate Paleontology, vol. 35, no. 2, e902846. https://doi.org/10.1080/02724634.2014.902846.

WILLIAMSON, S.A., EVANS, R.G., MANOLIS, S.C., WEBB, G.J. and REINA, R.D., 2017. Ecological and evolutionary significance of a lack of capacity for extended developmental arrest in crocodilian eggs. Royal Society Open Science, vol. 4, no. 12, pp. 171439. http://dx.doi.org/10.1098/rsos.171439. PMid:29308266. 